\title{
Study on the Difference of Urine Sediment Preparation for Microscopic Examination
}

\author{
Hyeok-Jae Lee $^{1}$, Chul Park ${ }^{2}$, Min-Young Seo ${ }^{1}$ \\ ${ }^{1}$ Department of Biomedical Laboratory Science, Gwangju Health University, Gwangju, Korea \\ ${ }^{2}$ Department of Biomedical Laboratory Science, Gwangyang Health College, Gwangyang, Korea
}

\section{현미경검사를 위한 요침사 표본제작에 따른 차이 연구}

\author{
이혁재 ${ }^{1}$, 박 철 ${ }^{2}$, 서민영 ${ }^{1}$

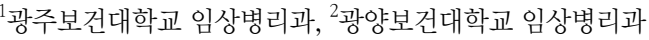

\begin{abstract}
Urinalysis is considered to be easier and simpler than other tests. It has been known to cause no burden to patients, while offering important information on diagnosing, treating, and determining the prognoses of kidney and urinary tract diseases. Urinary sediments are usually performed by microscopic examination of centrifuged urine by technologist. The guidelines proposed by the Korean Association of External Quality Assessment Service are actually different from those actually practiced by medical institutions and taught to biomedical students in textbooks. Therefore, we verified whether different sediment preparation methods lead different test results. Specimens that tested positive from the occult blood and leukocyte esterase in the urine dipstick test were randomly selected for a microscopic examination. The differences in the urine sediment preparation affected the sediment concentrations, which influenced the cell grade and cell number per HPF. The first factor in determining the sediment concentration is the centrifugal force. Many medical institutions use 1,500 rpm as the centrifugal speed without considering the radius of the centrifuge; such a value may not be accurate for $400 \mathrm{G}$. Consequently, there were differences in urine concentrations, which influenced the results. The second factor is the amount of sediment in urine. Different amounts of the remaining supernatant led to different sediment concentration factors, again, causing different results. Furthermore, not only by using a pipette to obtain an accurate amount as stipulated, but also by roughly obtaining a drop, the microscopic examination using such a volume of sediment examined affected the results. Therefore, this study highlights the importance of standardization of urine sediment preparation procedures to promote consistency and accuracy across institutions.
\end{abstract}

Key words: Microscopic examination, Urine sediment preparation, Cell grade, Standardization

This is an Open Access article distributed under the terms of the Creative Commons Attribution Non-Commercial License (http://creativecommons.org/licenses/by-nc/4.0) which permits unrestricted non-commercial use, distribution, and reproduction in any medium, provided the original work is properly cited.

Copyright $@ 2017$ The Korean Society for Clinical Laboratory Science. All rights reserved.
Corresponding author: Hyeok-Jae Lee

Department of Biomedical Laboratory Science, Gwangju Health University, Bungmun-daero,

Gwangsan-gu, Gwangju 62287, Korea

Tel: 82-62-958-7613

Fax: 82-62-958-7526

E-mail: primo-uomo@ghu.ac.kr

Received: October 18, 2017

Revised: October 25, 2017

Accepted: October 26, 2017

\section{서 론}

일상적인 소변검사(routine urinalysis)는 소변의 채취가 용 이하여 환자에게 주는 부담이 적으며, 매우 간편한 시약을 사용 하여 간단한 검사방법으로 검사가 이루어진다. 뿐만 아니라 검
사에 소요되는 시간이 짧아 임상적으로 매우 빈번히 시행되는 검사이다. 소변검사는 건강인 또는 환자의 진료과정에서 건강 진단이나 질병의 유무 등을 반영하는 보편화된 기본검사 가운 데 하나로 검사 결과는 임상적으로 매우 중요하다. 일상적인 소 변검사는 물리, 화학적 성상검사, 요침사 현미경검사(manual 
microscopy) 영역으로 나눌 수 있다[1]. 임상에서 소변의 화학 적 성상검사에 있어 초기에는 다양한 검사방법 및 시험지 등을 사용하였으나 현재는 다항목 동시측정 시험법인 요시험지봉검 사(dipstick urinalysis)법을 주로 이용하고 있다. 요시험지봉 검사법은 매우 간편하기 때문에 모든 의료기관에서 널리 사용 되고 있다[2].

시험지봉검사는 소변에 존재하는 다양한 산화물질, 환원물 질, 착색물질 등의 영향을 받아 위양성 또는 위음성 반응이 흔하 게 발생할 수 있어 결과의 해석에 주의해야 한다[3]. 소변에는 요 소(urea), 크레아티닌(creatinine) 등과 같은 유기성분들과 무 기성분인 각종 염류, 인산염 등이 존재하며 혈구, 원주, 상피세 포 및 각종 결정체 등이 출현한다[4]. 요시험지봉검사의 잠혈반 응(occult blood)이나 leukocyte esterase 검사로는 요 중 적혈 구나 백혈구의 존재만을 추측할 수 있다. 따라서 요침사 현미경 검사는 원심분리한 요에서 얻은 침사물을 현미경으로 관찰하여 유형성분의 유무와 결정체 등을 확인 감별하고 양을 판정하여 신장과 요로계통의 질환 진단 및 치료효과 판정뿐만 아니라 각 종 대사이상 질환, 전신성 질환의 조기발견을 위한 목적으로 임 상에서 가장 흔하게 시행되는 기본검사 중 하나이다[4-7].

요침사 현미경검사는 원심분리한 요를 현미경으로 검경하는 방법으로 현재까지 널리 시행되고 있으나 수작업이 많이 요구 되고 정밀도가 떨어지며, 검사 시간이 다소 오래 걸리는 등의 단 점을 가지고 있다[8]. 또한 현미경의 사용법에 대한 능숙함이 필 요하고 표준화된 요침사 표본제작과 침사물의 종류를 감별할 수 있는 전문적인 지식 및 숙련도가 요구되며, 판독방법의 차이 에 따른 주관적인 해석으로 재현성이 떨어지며 검사의 정도관 리가 쉽지 않아서 오류 발생할 가능성이 높을 뿐만 아니라 검사 실간 표준화가 어렵다[5,9-11]. 최근에는 검사결과의 정확도와 표준화정도를 향상시키기 위해 유세포분석원리(flow cytometry) 를 바탕으로 한 Sysmex UF-100 (Sysmex, Kobe, Japan)과 이 미지분석기술(image based analysis system)을 바탕으로 한 Iris iQ 200 system (Iris Diagnostics, Chatsworth, CA, USA) 등과 같은 여러 종류의 자동화 장비가 규모가 큰 의료기관에 도 입되어 운용되고 있다[12].

2015년 대한임상검사정도관리협회 요경검학분과에서 실시 한 추계학술대회에서 제시한 요경검 가이드라인 제안에 따른 표본제작과 실제 의료기관에서 시행되고 있는 표본제작 과정이 상이하고 임상병리학을 전공하는 학생들이 사용하고 있는 여러 교과서들의 내용도 서로 다른 부분이 많았다. 따라서 본 연구는 검사의 질관리 차원에서 서로 다른 표본제작으로 인해 검사 결 과에 차이가 있는지 확인하고자 하였다.

\section{재료 및 방법}

\section{1. 연구대상}

전남 순천 소재 $\mathrm{H}$ 병원 외래 및 입원 각과에서 의뢰한 환자의 요검체를 사용하였다. 검사 의뢰된 검체 중 요시험지봉검사에 서 잠혈반응과 leukocyte esterase 검사에서 양성으로 확인된 검체를 무작위로 선정하여 30 분 이내에 요침사 현미경검사를 시행하였다.

\section{2. 연구방법}

요중 적혈구와 백혈구를 확인하기 위한 검체는 요시험지봉 검사에 Uriscan Pro Semi-automatic Urine Analyzer (YD diagnostic, Yongin, Korea)를 이용하여 요시험지봉검사를 실 시하였다. 각 항목이 양성(1+ 정도)이고 세포의 변성을 최소화 시키기 위해 1.020 1.025 사이의 비중(specific gravity)과 $5.0 \sim 5.5$ 사이의 $\mathrm{pH}$ 결과를 보인 10 개 검체를 선별하여 각각 서 로 혼합하여 본 연구에 필요한 검체량(약 $250 \mathrm{~mL}$ )으로 조제하 여 표본제작 및 경검에 사용하였다. 표본제작을 위한 원심분리 에는 Hanil FLETA 5 (Hanil, Gimpo, Korea)로 swing type의 rotor이며, 반경이 $160 \mathrm{~mm}$ 인 원심분리기를 사용하였다. 원심 관은 눈금이 있는 원추형 플라스틱 관을 사용하였으며, 상청액 을 버린 후 침사량이 일정하게 남을 수 있도록 약 30초 정도 rack에 꽂아 둔 후각 방법에서 제시한 절차대로 제작하였다. 경 검 오차를 최소화하기 위해 임상경력 10년 이상의 숙련된 기술 을 가지고 있다고 사료되는 검사자 5 명이 각자의 표본을 제작하 여 경검하였다. 구경이 22 mm인 Nikon ECLIPSE E400 (Nikon, Tokyo, Japan) 현미경으로 각 방법에 따라 제작된 표본을 약확 대(low power field, 100 배)에서 전시야를 관찰한 후 강확대 (high power field, 400 배)에서 12 시야를 경검하여 이중 최소 값과 최대값을 보인 시야의 결과 값을 제외하고 10시야 결과를 가지고 적혈구(red blood cell, RBC)와 백혈구(white blood cell, WBC)의 평균(mean)과 표준편차(standard deviation)을 산출하였다. 검경 결과의 해석은 2014년도에 대한진단검사의 학회에서 발행한 진단검사의학 제5판(laboratory medicine fifth edition)에 의거하여 grading system (등급체계)로 보고 하였다[1].

1) 대한임상검사정도관리협회 2015년 요경검 가이드라인 원심관에 $10 \mathrm{~mL}$ 의 소변을 넣고 $400 \mathrm{G}$ (relative centrifugal force, $\mathrm{RCF}$ )에서 5 분 간 원심분리한 후 상청액을 버리고 남은 양이 $330 \pm 100 \mu \mathrm{L}$ 되게 한다. 침사물을 잔여 요와 균등히 혼합 
한 후 pipette를 이용하여 slide glass에 $20 \mu \mathrm{L}$ 을 옮긴 후 18 $\mathrm{mm} \times 18 \mathrm{~mm}$ cover slip를 덮어 침사가 균등히 분포되도록 한 후 약확대에서 전 시야를 관찰한 후 강확대에서 최저 10시야이 상을 관찰한 후 세포(적혈구, 백혈구) 수의 평균을 구하였다.

\section{2) Clinical and Laboratory Standards Institute (CLSI) POCT 10}

원심관에 $12 \mathrm{~mL}$ 의 소변을 넣고 $400 \mathrm{G}$ 에서 5 분간 원심분리 한 후 상청액을 버리고 남은 양을 가볍게 흔들어 잘 섞은 후 1 방 울을 슬라이드에 떨어뜨리고 현미경으로 우선 저배율에서 전체 적으로 관찰한 후 고배율에서 10시야 이상을 경검하였다. 그러 나 최종 침사량이나 농축 정도가 제시되어 있지 않아서 시험관 을 순간적으로 약 1 초간 거꾸로 하여 상청액을 버린 후 여분의 상청액과 침사물을 잘 혼합한 다음 한 방울을 slide 위에 떨어뜨 린 후 cover glass를 덮고 경검하였다.

\section{3) 진단검사의학 2014년 제5판}

원심관에 $10 \mathrm{~mL}$ 의 소변을 넣고 $450 \sim 500 \mathrm{G}$ 에서 5분간 원심 분리하여 상청액을 버린 후 남은 양이 $1 \mathrm{~mL}$ (10배 농축) 또는 $0.5 \mathrm{~mL}$ (20배 농축)가 되게 한 후 가볍게 흔들어 잘 혼합시킨다. 침사물 1 방울을 슬라이드에 점적하여 침사가 균등히 분포되도 록 한 후 약확대에서 전 시야를 관찰한 후 강확대에서 최저 10시

Table 1. Cell and cast grading system

\begin{tabular}{cccc}
\hline Grade & Cells/HPF & Grade & Casts/LPF \\
\hline Grade 1 & $<1$ & Grade 1 & $<1$ \\
Grade 2 & $1 \sim 4$ & Grade 2 & $1 \sim 2$ \\
Grade 3 & $5 \sim 9$ & Grade 3 & $3 \sim 5$ \\
Grade 4 & $10 \sim 29$ & Grade 4 & $6 \sim 10$ \\
Grade 5 & $\geq 30$ & Grade 5 & $11 \sim 20$ \\
Grade 6 & $\geq 1 / 2$ of field of view & Grade 6 & $\geq 20$ \\
\hline
\end{tabular}

Abbreviations: HPF, high power field; LPF, low power field. Source: Textbook of Laboratory Medicine, 5th ed, 2014.
야 이상을 관찰한 후 세포수의 평균을 구하였다.

\section{4) 요화학 및 체액검사 2011년 제2판}

원심관에 10 15 mL의 소변을 넣고 2,000 rpm (revolution per minute)으로 5 분간 원심분리한 후 침사물이 부유되지 않게 상청액을 제거하여 소변과 침사물이 정확히 $1 \mathrm{~mL}$ 이 되게 한다. 침사물을 균등히 부유시킨 후 1 방울을 slide glass에 떨어뜨린 후 cover slip를 덮어 약확대에서 전시야를 관찰한 후강확대에 서 최저 10시야 이상을 관찰한 후 세포수의 평균을 구하였다.

\section{3. 결과 기준과 보고단위}

실제 임상에서 사용되고 있는 정성적인 결과 보고는 혈구 등 의 세포, 결정체와세균 등은 강확대에서 원주는 약확대에서 시 야 당 평균 개수를 보고하거나 grade 단위로 보고하는 것이 일 반적이다(Table 1).

\section{4. 통계 분석}

자료의 통계처리는 SPSS version 18.0 (SPSS, Chicago, USA) 통계프로그램을 이용하였다. 검체에 대한 적혈구와 백혈 구 분포는 평균과 표준편차로 분석하였으며, 검사방법에 따른 검사자간의 적혈구 및 백혈구 평균비교는 t-test와 ANOVA test 를 시행하였다. 모든 통계량의 유의수준은 $p<0.05$ 로 하였다.

\section{결 과}

\section{1. 적혈구에 대한 각 방법 비교}

동일한 검체를 4 가지 방법으로 표본을 제작하여 적혈구를 비 교하였다. 대한임상검사정도관리협회에서는 grade 4, CLSI POCT 10은 grade 5, 진단검사의학 서적에서는 2 명의 검사자 에서 grade 3 결과와 3 명의 검사자에서 grade 4 를 보였으며, 요 화학 및 체액검사 서적 방법으로는 1 명의 검사자에서 grade 4 결과와 4 명의 검사자에서 grade 3 결과를 보였다. 4 가지 방법

Table 2. Comparison of each methods between manual microscopy

\begin{tabular}{lcccccc}
\hline \multicolumn{1}{c}{ Method } & \multirow{4}{c}{ Component } & \multicolumn{4}{c}{ Result (mean, SD) } \\
\cline { 3 - 7 } & & Surveyor 1 & Surveyor 2 & Surveyor 3 & Surveyor 4 & Surveyor 5 \\
\hline KAEQAS & $\mathrm{RBCs}$ & $14.5 \pm 3.2$ & $13.7 \pm 2.9$ & $13.4 \pm 2.0$ & $13.4 \pm 2.2$ & $14.7 \pm 3.4$ \\
CLSI POCT 10 & $\mathrm{RBCs}$ & $35.8 \pm 3.8$ & $34.7 \pm 6.9$ & $33.8 \pm 6.3$ & $31.3 \pm 4.7$ & $36.1 \pm 4.2$ \\
Textbook of Laboratory Medicine & $\mathrm{RBCs}$ & $6.7 \pm 1.7$ & $12.1 \pm 2.7$ & $11.9 \pm 2.4$ & $9.4 \pm 2.4$ & $10.8 \pm 1.5$ \\
Textbook of Urinalysis and Body fluids & $\mathrm{RBC}$ & $9.4 \pm 2.3$ & $8.8 \pm 3.1$ & $8.9 \pm 2.4$ & $7.8 \pm 1.5$ & $11.4 \pm 2.9$ \\
$p$-value & & $<0.001$ & $<0.001$ & $<0.001$ & $<0.001$ & $<0.001$ \\
\hline
\end{tabular}

Abbreviations: KAEQAS, Korean Association of External Quality Assessment Service; CLSI POCT 10, Clinical and Laboratory Standards Institute Point-of-Care Testing 10; RBC, red blood cell. 
중 CLSI POCT 10에서 평균값이 가장 높았으며, 4 가지 방법 간 의 평균값은 통계적으로 유의한 차이가 있었다 $(p<0.001)$ (Table 2).

\section{2. 백혈구에 대한 각 방법 비교}

동일한 검체를 4 가지 방법으로 표본을 제작하여 백혈구를 비 교하였다. 대한임상검사정도관리협회에서는 grade 4, CLSI POCT 10은 grade 5, 진단검사의학 서적에서는 grade 3 결과 를 보였으며, 요화학 및 체액검사 서적 방법으로는 1명의 검사 자에서 grade 2 결과와 나머지 4 명에서 grade 3 결과를 보였다. 4가지 방법 중 CLSI POCT 10에서 평균값이 가장 높았으며, 4 가지 방법 간의 평균값은 통계적으로 유의한 차이가 있었다 $(p<0.001)$ (Table 3).

\section{3. 원심력 차이에 따른 비교}

원심분리 속도를 $1,500 \mathrm{rpm}$ 으로 고정하고 반경을 $120 \mathrm{~mm}$, $160 \mathrm{~mm}, 200 \mathrm{~mm}$ 로 가정하여 RCF=1.12 $\times$ Radius $\times(\mathrm{rpm} /$ $1,000)^{2}$ 식에서 각각의 RCF값을 구한 후 Hanil FLETA 5 (160 $\mathrm{mm}$ ) 원심분리기를 사용하여 아래의 조건별로 원심분리 하여 대한임상검사정도관리협회에서 제시한 방법으로 표본을 제작 하여 원심력에 따른 차이를 비교하였다. $302 \mathrm{G}$ 에서 적혈구는 5 명의 검사자 모두 grade 3 결과를 보였고, 백혈구도 5 명의 검사
자 모두 grade 4 결과를 보였다. $403 \mathrm{G}$ 에서 적혈구는 5명의 검 사자 모두 grade 3 결과를 보였고, 백혈구는 5명의 검사자 모두 grade 4 결과를 보였다. 마지막으로 $504 \mathrm{G}$ 에서 적혈구는 5명의 검사자 모두 grade 3 결과를 보였으며, 백혈구는 1 명의 검사자 는 grade 3 를 4 명의 검사자는 grade 4 결과를 보였다. 원심력 차 이에 따라 검사방법 간의 적혈구 평균값은 통계적으로 유의한 차이가 있었으며 $(p<0.001)$, 백혈구 평균값은 1 번 검사자와 4 번 검사자에서 검사방법 간 통계적으로 유의한 차이를 보이지 않았다(Table 4).

\section{4. 상청액 제거 후 침사량 비교}

대한임상검사정도관리협회에서 제시한 표본제작 방법으로 원심관에 $10 \mathrm{~mL}$ 의 소변을 넣고 $400 \mathrm{G}$ 에서 5 분 간 원심분리 후 상청액을 버리고 침사물의 양이 $0.3 \mathrm{~mL}$ (농축계수: 33 )과 1.0 $\mathrm{mL}$ (농축계수: 10)되게 하여 서로 비교하였다. 실제로는 대한 임상검사정도관리협회에서 제안한 침사량은 $0.33 \mathrm{~mL}$ 이었으 나 정확한 용량 측정이 힘들어 $0.3 \mathrm{~mL}$ 로 설정하여 검사하였다. $0.3 \mathrm{~mL}$ 에서 적혈구는 5명의 검사자 모두 grade 3 결과를 보였 고, 백혈구는 5 명의 검사자 모두 grade 5 결과를 보였다. $1.0 \mathrm{~mL}$ 에서 적혈구는 5 명의 검사자 모두 grade 2 결과를 보였고, 백혈 구는 5명의 검사자 모두 grade 4 결과를 보였다. 상청액 제거 후 침사량에 따른 검사방법 간 적혈구와 백혈구의 평균값은 검사

Table 3. Comparison of each methods between manual microscopy

\begin{tabular}{lcccccc}
\hline \multicolumn{1}{c}{ Method } & \multirow{5}{c}{ Component } & \multicolumn{4}{c}{ Result (mean, SD) } \\
\cline { 3 - 7 } & & Surveyor 1 & Surveyor 2 & Surveyor 3 & Surveyor 4 & Surveyor 5 \\
\hline KAEQAS & WBCs & $12.3 \pm 2.5$ & $12.7 \pm 4.3$ & $13.9 \pm 2.6$ & $13.5 \pm 2.7$ & $13.3 \pm 2.4$ \\
CLSI POCT 10 & WBCs & $32.3 \pm 2.9$ & $32.7 \pm 2.8$ & $30.5 \pm 1.8$ & $31.0 \pm 2.0$ & $30.5 \pm 1.8$ \\
Textbook of Laboratory Medicine & WBCs & $7.4 \pm 1.3$ & $8.7 \pm 1.5$ & $7.3 \pm 1.3$ & $6.9 \pm 1.4$ & $6.6 \pm 1.3$ \\
Textbook of Urinalysis and Body fluids & WBCs & $4.3 \pm 0.9$ & $5.4 \pm 1.0$ & $7.3 \pm 1.2$ & $7.2 \pm 1.3$ & $7.9 \pm 1.8$ \\
$p$-value & & $<0.001$ & $<0.001$ & $<0.001$ & $<0.001$ & $<0.001$ \\
\hline
\end{tabular}

Abbreviation: WBC, white blood cell.

Table 4. Comparison of each centrifugal conditions between manual microscopy

\begin{tabular}{lcccccc}
\hline \multirow{2}{*}{ Centrifugation condition } & \multirow{5}{*}{ Component } & \multicolumn{5}{c}{ Result (mean, SD) } \\
\cline { 3 - 7 } & & Surveyor 1 & Surveyor 2 & Surveyor 3 & Surveyor 4 & Surveyor 5 \\
\hline $120 \mathrm{~mm}, 1,500 \mathrm{rpm}(302 \mathrm{G})$ & $\mathrm{RBC}$ & $5.6 \pm 1.4$ & $6.0 \pm 1.1$ & $6.0 \pm 1.0$ & $5.5 \pm 1.0$ & $6.4 \pm 1.1$ \\
$160 \mathrm{~mm}, 1,500 \mathrm{rpm}(403 \mathrm{G})$ & $\mathrm{RBC}$ & $7.3 \pm 0.8$ & $8.5 \pm 1.3$ & $8.5 \pm 1.3$ & $9.3 \pm 1.7$ & $9.0 \pm 1.2$ \\
$200 \mathrm{~mm}, 1,500 \mathrm{rpm}(504 \mathrm{G})$ & $\mathrm{RBCs}$ & $8.5 \pm 0.7$ & $8.8 \pm 1.0$ & $8.9 \pm 1.8$ & $8.7 \pm 0.9$ & $9.2 \pm 1.0$ \\
$p$-value & & $<0.001$ & $<0.001$ & $<0.001$ & $<0.001$ & $<0.001$ \\
$120 \mathrm{~mm}, 1,500 \mathrm{rpm}(302 \mathrm{G})$ & WBCs & $10.3 \pm 1.2$ & $10.8 \pm 1.0$ & $10.4 \pm 1.0$ & $11.5 \pm 1.7$ & $10.6 \pm 1.2$ \\
$160 \mathrm{~mm}, 1,500 \mathrm{rpm}(403 \mathrm{G})$ & WBCs & $11.6 \pm 2.4$ & $11.7 \pm 1.6$ & $12.0 \pm 1.7$ & $12.1 \pm 1.4$ & $12.4 \pm 1.4$ \\
$200 \mathrm{~mm}, 1,500 \mathrm{rpm}(504 \mathrm{G})$ & WBCs & $12.0 \pm 1.6$ & $9.2 \pm 1.1$ & $12.8 \pm 0.6$ & $12.7 \pm 1.2$ & $12.6 \pm 1.5$ \\
$p$-value & & 0.104 & $<0.001$ & $<0.001$ & 0.203 & 0.005 \\
\hline
\end{tabular}


자 모두 $0.3 \mathrm{~mL}$ 에서 가장 높았으며, 통계적으로 유의한차이가 있었다 $(p<0.001)$ (Table 5).

\section{Slide glass에 떨어뜨린 침사량 차이}

대한임상검사정도관리협회에서 제시한 표본제작 방법으로 원심관에 $10 \mathrm{~mL}$ 의 소변을 넣고 $400 \mathrm{G}$ 에서 5 분간 원심분리 후 상청액을 버리고 침사물의 양이 $0.3 \mathrm{~mL}$ 되게 하였다. 잔여 요와 균등히 혼합한 후 pipette를 이용하여 slide glass에 각각 $12 \mu \mathrm{L}$, $20 \mu \mathrm{L}, 35 \mu \mathrm{L}$ 을 옮긴 후 $18 \mathrm{~mm} \times 18 \mathrm{~mm}$ cover slip를 덮어 침 사가 균등히 분포되도록 한 후 침사량의 차이에 따른 결과를 서 로 비교하였다. $12 \mu \mathrm{L}$ 에서 적혈구, 백혈구 검경에 있어 5명 검 사자 모두 grade 3 결과를 보였다. $20 \mu \mathrm{L}$ 에서 적혈구, 백혈구 검 경에 있어 5 명 검사자 모두 grade 4 결과를 보였다. 마지막으로 $35 \mu \mathrm{L}$ 에서 적혈구는 5 명의 검사자 모두 grade 4 결과를 보였으 며, 백혈구는 1 명의 검사자는 grade 5 를 나머지 4 명의 검사자는 grade 4 결과를 보였다. Slide glass에 떨어뜨린 침사량에 따른 검사방법 간 적혈구와 백혈구의 평균값은 검사자 모두 $35 \mu \mathrm{L}$ 에 서 가장 높았으며, 통계적으로 유의한 차이가 있었다 $(p<0.001)$ (Table 6).

\section{고 찰}

지난수십 년 동안 과학기술의 발달로 자동화, 전산화가 급속 도로 이루어지면서 진단검사와 같은 의료분야에 많은 영향을 주었다. 요검사 분야도 많은 발전을 거듭해 왔으나 요침사 보다 요정성검사의 자동화가 상당히 이루어져 검사의 질 향상, 업무 의 효율성 등 여러 가지 측면을 향상시켰으며, 결과 보고시간 단 축에도 상당한 도움이 되었다[13]. 그러나 대한임상검사정도관 리협회 요경검학분과에서 실시된 전국 요검사 정도관리현황을 통해서 알 수 있듯이 요침사 부분의 표준화와 정도관리는 매우 어려운 난제 중의 하나라고 하였다[14].

유세포분석법이나 이미지분석법이 적용된 자동화 요침사 검 사 기기가 개발 보급됨에 따라 현미경으로 요침사를 관찰해야 하는 절대적 빈도가 줄어든 것은 사실이다. 이러한 요침사 자동 화분석 장비를 이용하여 검사를 수행할 경우 침사결과의 정량 화, 높은 재현성을 얻을 수 있어 보다 객관적인 검사결과를 제공 할 뿐만 아니라 처리 능력이 높아 생산성 향상을 기대할 수 있다. 또한 미량으로도 측정이 가능하므로 신생아 등의 검체에도 용 이한 장점이 있다[12,15]. 현재는 기기의 고가로 인하여 경제성 때문에 보편적 사용은 어려우나 정도관리 등의 필요성 증가로 앞으로 도입이 점점 증가할 것이며, 향후 요침사자동화가 상당 히 진행될 것으로 기대된다[14]. 그러나 여러 가지 현실적인 문

Table 5. Comparison of the difference between each volume of residual sediment after removal of supernatant (concentration factor, CF)

\begin{tabular}{lcccccc}
\hline \multirow{2}{*}{$\begin{array}{c}\text { Volume of residual } \\
\text { sediment (CF) }\end{array}$} & Component & \multicolumn{5}{c}{ Result (mean, SD) } \\
\cline { 3 - 7 } & & Surveyor 1 & Surveyor 2 & Surveyor 3 & Surveyor 4 & Surveyor 5 \\
\hline $0.3 \mathrm{~mL}(33)$ & $\mathrm{RBC} s$ & $9.1 \pm 1.7$ & $8.1 \pm 0.9$ & $8.1 \pm 1.0$ & $8.9 \pm 0.7$ & $9.6 \pm 1.1$ \\
$1.0 \mathrm{~mL}(10)$ & $\mathrm{RBC} S$ & $4.0 \pm 0.9$ & $3.6 \pm 1.0$ & $2.6 \pm 0.5$ & $2.4 \pm 0.5$ & $2.5 \pm 0.5$ \\
$p$-value & & $<0.001$ & $<0.001$ & $<0.001$ & $<0.001$ & $<0.001$ \\
$0.3 \mathrm{~mL}(33)$ & $\mathrm{WBC}$ & $30 \uparrow$ & $30 \uparrow$ & $30 \uparrow$ & $30 \uparrow$ & $30 \uparrow$ \\
$1.0 \mathrm{~mL}(10)$ & $\mathrm{WBC}$ & $16.3 \pm 2.4$ & $17.5 \pm 1.4$ & $15.8 \pm 1.5$ & $16.1 \pm 2.1$ & $16.6 \pm 1.6$ \\
$p$-value & & $<0.001$ & $<0.001$ & $<0.001$ & $<0.001$ & $<0.001$ \\
\hline
\end{tabular}

Table 6. Comparison of the difference between each volume of sediment dropped on the slide

\begin{tabular}{|c|c|c|c|c|c|c|}
\hline \multirow{2}{*}{$\begin{array}{l}\text { Sediment volume } \\
\text { dropped }\end{array}$} & \multirow{2}{*}{ Component } & \multicolumn{5}{|c|}{ Result (mean, SD) } \\
\hline & & Surveyor 1 & Surveyor 2 & Surveyor 3 & Surveyor 4 & Surveyor 5 \\
\hline $12 \mu \mathrm{L}$ & $\mathrm{RBC}_{\mathrm{S}}$ & $7.0 \pm 0.4$ & $6.2 \pm 1.5$ & $6.1 \pm 0.7$ & $8.1 \pm 0.7$ & $8.6 \pm 1.2$ \\
\hline $20 \mu \mathrm{L}$ & $\mathrm{RBC}_{s}$ & $10.4 \pm 1.6$ & $11.1 \pm 1.1$ & $11.1 \pm 1.0$ & $10.9 \pm 0.7$ & $10.7 \pm 1.2$ \\
\hline $35 \mu \mathrm{L}$ & $\mathrm{RBC}_{\mathrm{S}}$ & $20.6 \pm 3.1$ & $23.1 \pm 1.3$ & $24.2 \pm 2.3$ & $23.0 \pm 2.4$ & $22.2 \pm 2.7$ \\
\hline$p$-value & & $<0.001$ & $<0.001$ & $<0.001$ & $<0.001$ & $<0.001$ \\
\hline $12 \mu \mathrm{L}$ & WBCs & $9.1 \pm 1.5$ & $7.4 \pm 1.3$ & $9.1 \pm 1.1$ & $7.6 \pm 1.3$ & $8.1 \pm 1.2$ \\
\hline $20 \mu \mathrm{L}$ & $W_{B} C_{s}$ & $14.5 \pm 2.0$ & $14.0 \pm 1.8$ & $13.4 \pm 1.8$ & $14.3 \pm 2.2$ & $15.5 \pm 1.4$ \\
\hline $35 \mu \mathrm{L}$ & $W_{B}$ & $30.9 \pm 6.3$ & $29.0 \pm 4.8$ & $26.5 \pm 3.0$ & $29.0 \pm 4.2$ & $28.9 \pm 2.8$ \\
\hline$p$-value & & $<0.001$ & $<0.001$ & $<0.001$ & $<0.001$ & $<0.001$ \\
\hline
\end{tabular}


제로 상급의료기관을 제외한 절대 다수의 의료기관에서의 요침 사자동화 기기의 사용을 기대하기는 어렵다. 따라서 요 현미경 검사는 여전히 수기법으로 표본을 제작하여 현미경을 통해 검 사자의 눈으로 판독해야 할 것이다.

요침사 현미경검사는 표본제작의 표준화와 정도관리가 어렵 고 판독에 주관적인 견해가 개입될 수 있어 검사실, 검사자 간 요 침사 결과에 차이가 발생할 수 있다. 동일한 환자라도 결과가 제 각각 다를 수 있어 정확도 및 재현성에 문제가 발생할 수 있다. 따라서 정확도와 재현성을 높이기 위해서는 숙련된 검사자가 요구된다. 또한 요경검 표본제작 시 원심분리 속도 및 시간, 요 검체 량, 침사량 등의 여러 요인에 의해 cell grade에 영향을 준 다[16]. 표본제작의 표준화를 위해 2015년도에 대한임상검사 정도관리협회 추계학술대회에서 제안한 요경검 가이드라인을 살펴보면, 원심관에 소변 $10 \mathrm{~mL}$ 을 넣은 후 $400 \mathrm{G}$ 로 5분간 원심 분리 시킨 후 $20 \mu \mathrm{L}$ 침사물을 slide glass에 떨어뜨린 후 $18 \times 18$ $\mathrm{mm}$ cover slip으로 덮고 경검하도록 제안하였다.

1996년 대한임상검사정도관리협회 임상경검학분과 위원회 에서 국내 요검사 실태 조사자료에 의하면 그 당시 요침사실시 기관수가 262 기관이었고, 요침사 표본제작을 위한 원심속도는 $1,500 \mathrm{rpm}$ 을 사용하는 기관이 $63.2 \%$ (158 기관), 요침사잔류 량은 $0.1 \mathrm{~mL}$ 이 $25.4 \%$ (66 기관), $0.2 \mathrm{~mL}$ 이 $37.3 \%$ (97 기관), $0.3 \mathrm{~mL}$ 이 $16.9 \%$ (44 기관)로 조사되었다[6]. 대한임상검사정 도관리협회 요경검학분과에 의해 2008년도에 627기관을 대상 으로 실시한 원심분리기 반경, 원심분리속도, 잔사량(농축계수) 등을 조사한 결과에 의하면, 원심분리기 반경은 $125 \mathrm{~mm}$ 에서 $190 \mathrm{~mm}$ 까지 다양하였고, 원심력은 평균 $501 \mathrm{G}(130 \mathrm{G}$ $1,145 \mathrm{G}$ )로 나타났으며, 33 기관(12.5\%)에서 $400 \mathrm{G}$ 이하, 144 기관(54.8\%)에서 $400 \mathrm{G} 550 \mathrm{G}$ 를 86 기관(32.7\%)에서 $550 \mathrm{G}$ 이상을 사용하고 있었으며, 침사량은 적게는 $0.2 \mathrm{~mL}$ 에서 많게 는 $1.0 \mathrm{~mL}$ 로 다양하였다.

정확한 판독만큼이나 중요한 사항은 요침사 현미경검사를 위한 표본제작이라고 할 수 있을 것이다. 각 의료기관의 요 현미 경검사 지침서와 실제 시행되고 있는 과정을 확인한 바에 의하 면, 요 농축 배수를 결정짓는 인자 가운데 하나인 원심분리 속도 에 있어서도 rpm을 사용하는 기관과 $\mathrm{G}$ 를 사용하는 기관으로 나뉘어져 있었다. 중, 소형 의료기관 뿐만 아니라 대형 의료기관 에서도 rpm 단위를 주로 사용하고 있었으며, 원심속도는 대부 분 $1,500 \mathrm{rpm}$ 있었다. $G$ 를 사용하고 있는 기관은 일반적으로 $400 \mathrm{G}, 450 \mathrm{G}, 500 \mathrm{G}$ 중 한 가지를 선택하여 적용하고 있었다. 대한진단검사의학회 임상화학분과위원회와 대한임상화학회 에서 최근에 실시한 요침사 검사의 표준화를 위한 기초 자료 수
집 결과에서도 16 기관 중 11 기관에서 $400 \sim 499 \mathrm{G}$ 를 $500 \mathrm{G}$ 이상은 3 기관, $400 \mathrm{G}$ 이하는 2 기관으로 조사되었다. 임상병리 학을 전공하는 학생들의 교과서에는 주로 $\mathrm{G}$ 로 많이 제시되어 있었으며, 마찬가지로 이들 셋 중 하나가 제시되어 있었다.

$1,500 \mathrm{rpm}$ 은 원심분리기의 반경이 $160 \mathrm{~mm}$ 인 경우에 $\mathrm{G}$ 로 환산했을 때 $403 \mathrm{G}$ 에 해당된다. 대한임상검사정도관리협회 요 경검학분과의 2008년도 조사에 의하면, 원심분리기 반경이 $125 \mathrm{~mm}$ 에서 $190 \mathrm{~mm}$ 까지 다양하였다. 이처럼 각 기관에서 사 용하는 원심분리기의 반경이 제각각인 점을 고려해 볼 때 대부 분의 의료기관에서 사용하는 $1,500 \mathrm{rpm}$ 은 실제 $302 \mathrm{G}$ 에서 $479 \mathrm{G}$ 까지 다양할거라는 해석이 가능하다. 원심분리 속도가 요 농축에 영향을 준다고 알려져 있어서 세 가지 조건으로 설정하 여 실험하였다. 적혈구와 백혈구 모두 검사자에서 같은 grade 를 보였으나, 시야당 평균 개수 보고 방식으로는 약간의 차이가 있음을 확인할 수 있었다. 통계적으로도 원심력 차이에 따라 적 혈구 평균값은 유의한 차이가 있었으며 $(p<0.001)$, 백혈구 평 균 값도 3 명의 검사자에서 유의한 차이를 보였다. 따라서 회전 수가 똑같아도 원심분리기의 반경에 따라 원심관 바닥에 걸리 는 원심력이 다르기 때문에 회전수를 산출하는 공식에 대입하 여 해당 기관의 원심분리 속도를 반드시 구하여 사용해야 할 것 으로 사료된다.

요 농축 배수를 결정짓는 또 다른 중요한 인자는 요 침사량이 다. 대부분 의료기관의 표준안은 요 $10 \mathrm{~mL}$ 을 원심관에 넣고 원 심분리 후 상청액을 버리고 $1 \mathrm{~mL}$ 을 취하라고 되어 있으나, 실제 검사시 피펫으로 일일이 $1 \mathrm{~mL}$ 을 취하기가 쉽지 않고 피펫팅 과 정에서 침사물이 풀어질 수도 있어 시험관을 순간적으로 약 1 초 간 거꾸로 하여 상청액을 버린 후 다시 바로 세워 여분의 상청액 이 흘러 모이게 한 후 잘 혼합한 다음 한 방울(0.01 0.02 mL)을 slide 위에 떨어뜨린 후 cover glass를 덮고 경검한다고 기록되 어 있었으며, 실제로 이대로 시행하고 있었다.

대한진단검사의학회 임상화학분과위원회와 대한임상화학 회에서 최근에 실시한 요침사 검사의 표준화를 위한 기초 자료 수집 결과를 보면 최종 침사물의 량이 9기관에서 $0.5 \mathrm{~mL}$ (농축 계수: 20), 1 기관에서 $0.4 \mathrm{~mL}$ (농축계수: 25 ), 3 기관에서 0.2 $\mathrm{mL}$ (농축계수: 50 ), 기타는 4기관으로 조사되었다. 이처럼 표본 제작에 사용되는 침사량의 양이 검사실 마다 다름을 확인할 수 있었다. 본 연구에서도 침사량 차이에 따른 결과 변화를 확인하 였다. 실제 대한임상검사정도관리협회에서 제안한 침사량은 $0.33 \mathrm{~mL}$ 이었으나, 정확한 용량 측정이 어려워 $0.3 \mathrm{~mL}$ 로 설정 하여 실험하였다. grade 단위로 보고하는 방식에서는 1 grade 정도의 차이를 보였고, 시야 당 평균 개수를 보고하고 방식에서 
는 약 2 배 정도의 차이가 있었음을 확인할 수 있었다. 통계적으 로도 검사방법 간 적혈구와 백혈구의 평균값은 유의한 차이가 있었다 $(p<0.001)$. 대부분의 검사실에서 원심관을 순간적으로 약 1 초간 거꾸로 하여 상청액을 제거한다고 하였다. 이는 검사 자 마다 제거하는 상청액에 차이가 발생하여 남는 침사량의 농 축배수가 달라져서 결과에 영향을 미칠 수 있을 것이다.

뿐만 아니라 대부분의 검사실에서 침사량을 잘 부유시킨 후 한 방울을 slide 위에 떨어뜨린 후 경검한다고 하였으나, 한 방울 의 정확한 용량이 정해져 있지 않았다. 대한진단검사의학회 임 상화학분과위원회와 대한임상화학회에서 최근에 실시한 요침 사 검사의 표준화를 위한 기초 자료 수집 결과에서도 18 기관 중 17 기관에서 slide glass에 떨어뜨리는 양이 정해져 있지 않았다 고 보고하였다. 따라서 본 연구에서도 검사자간 떨군 용량의 차 이로 인해서 결과에 영향을 주는지 확인하였다. 떨어뜨린 용량 이 증가하면 결과 값도 같이 증가하는 것을 확인할 수 있었다. grade 단위로 보고하는 방식에서는 1 grade 정도의 차이를 보 였지만, 시야 당 평균 개수 보고에서는 용량에 따라 적게는 2 배, 많게는 4 배 정도의 차이가 있었음을 확인할 수 있었다. 통계적 으로도 검사방법 간 적혈구와 백혈구의 평균값은 유의한 차이 가 있었다 $(p<0.001)$. 대략적으로 원심관을 거꾸로 잡고 slide glass 위에 뚝 쳐서 한 방울을 떨군 후 경검 한다고 했는데 이는 검사자 마다 떨군 용량의 차이가 많이 발생할 수 있어 결과에 더 큰 영향을 줄 것으로 사료된다.

그러나 본 연구에서는 몇 가지 제한점이 있다. 첫째, 동일한 조건하에서 많은 검체를 대상으로 실험이 진행되기 어려운 현 실적 관계로 연구결과의 일반화에 한계가 있다. 또한 시간이 경 과할수록 세포들의 변성이나 용해 등으로 인한 영향에 대해 고 려하지 못하였다. 둘째, 검사자 각자가 표본을 제작하여 약확대 에서 세포의 분포 정도를 확인 후 경검을 하였으나, 같은 검체 내 에서도 세포의 분포 정도가 달라서 검사자 간 어떤 시야를 선택 하여 경검하느냐에 따라서도 서로 다른 결과가 도출될 수 있는 제한점이 있다. 통계의 유의성을 나타내려면 충분한 검체의 검 사결과와 제한점들을 보완하는 연구가 포함된다면 좀 더 정확 한 결과를 얻을 수 있을 것으로 기대된다.

그럼에도 불구하고 요침사 현미경적 검사에 있어 결과에 영 향을 미치는 중요한 인자는 상청액을 버린 후 남는 침사물의 양 (농축계수)과 부유시켜 slide glass에 떨어뜨린 침사량 이었다. 원심분리 속도도 결과에 영향을 주는 것으로 확인되었다. 따라 서 일관성 있고 보다 정확한 검사결과를 위해 반드시 2015년 대 한임상검사정도관리협회 추계학술대회에서 제안한 표본제작 과정으로 표준화가 이루어 져야 할 것이며, 제안한 요경검 가이
드라인을 모든 의료기관에서 잘 준수할 수 있도록 협회의 지속 적인 관심과 홍보가 필요할 것이다. 또한 요화학 교과서들도 일 관성 있게 통일하여 임상병리학을 전공하는 학생뿐만 아니라 교수자들의 혼란도 없애는 노력도 필요하다고 사료된다.

\section{요 약}

소변검사는 다른 검사에 비해 쉽고 간편하면서도 환자에게 부담이 없는 검사로 신장 및 요로계 질환의 진단, 치료 및 예후 결정에 중요한 정보를 제공한다. 요 침전물은 일반적으로 원심 분리된 소변을 검사자가 현미경을 통한 검경에 의해 이루어진 다. 대한임상검사정도관리협회에서 제안한 가이드라인과 실제 로 의료기관에서 시행되고 있는 내용이 다르고 임상병리학을 전공하는 학생들이 사용하고 있는 서적에 제시된 내용도 서로 차이가 있었다. 따라서 요 침전물 표본제작에 따른 차이가 검사 결과에 영향을 주는지 확인하기 위하여. 요시험지봉검사에서 잠혈반응과 백혈구 에스터라아제 검사 결과 양성으로 확인된 검체를 무작위로 선별하여 현미경적 검사를 시행하였다. 요 침 전물 표본제작차이는 요 농축 배수에 영향을 주어 cell grade나 시야당 평균 세포수 결과에 영향을 미쳤다. 침전물의 농도를 결 정짓는 첫 번째 요소는 원심력이다. 그러나 많은 의료기관에서 원심분리기 반경을 고려하지 않는 채 $1,500 \mathrm{rpm}$ 을 사용하고 있 었으며 이는 $400 \mathrm{G}$ 라는 정확한 원심력을 얻을 수 없었다. 결과 적으로 요 농축에 있어 차이가 발생하여 결과에도 영향을 미쳤 다. 두 번째 요소는 요 침사물의 양이다. 제거하고 남은 요의 상 청액의 양은 요 침사물의 농축 계수에 영향을 주어 다른 결과를 초래하였다. 뿐만 아니라 피펫을 사용하여 제시된 정확한 용량 을 취하지 않고 대략적으로 한 방울을 떨어뜨린 후 경검했을 때 도 결과에 영향을 주었다. 따라서 일관성 있고 보다 정확한 검사 결과를 위해 반드시 표본제작 과정이 표준화가 되어야할 것이다.

Acknowledgements: This paper was supported by Gwangju Health University in 2016 (3016003).

Funding: None

Conflict of interest: None

\section{REFERENCES}

1. Kim KD. Urinalysis and body fluid analysis. Korean society for laboratory medicine, Laboratory Medicine. 5th ed. Seoul: E-public; 2014. Chap 497-508.

2. Shin SY, Kwon MJ, Woo HY, Park HS, Kim YJ. Preliminary eval- 
uation of the URISCAN SUPER and usefulness of a new urine reagent strip to detect ascorbic acid. J Lab Med Qual Assur. 2011;33(2):63-69.

3. Tae-Hee Han. Urinalysis: The usefulness and limitations of urine dipstick testing. J Korean Soc Pediatr Nephrol. 2013; 17(2):42-48.

4. Fuller CE, Threatte GA, Henry JB. Basic examination of urine. In: Henry JB, ed. Clinical diagnosis and management by laboratory methods. 20th ed. Philadelphia: WB Saunders; 2001. Chap 367-402.

5. Hemmelgarn BR, Manns BJ, LIoyd A, James MT, Klarenbach S, Quinn RR, et al. Relation between kidney function, proteinuria and adverse outcomes. JAMA. 2010;303(5):423-429.

6. Huussen J, Koene RA, Hilbrands LB. The urinary sediment a simple and useful diagnostic tool in patients with haematuria. Neth J Med. 2004;62(1):4-9.

7. Simerville JA, Maxted WC, Pahira JJ. Urinalysis: a comprehensive review. Am Fam Physician. 2005;71(6):1153-1162.

8. Ben-Ezra J, Bork L, McPherson RA. Evaluation of the sysmex UF-100 automated urinalysis analyzer. Clin Chem. 1998;44(1): 92-95.

9. Winkel P, Statland BE, Jorgensen K. Urine microscopy an ill-defined method, examined by a multifactorial technique. Clin Chem. 1974;20(4):436-439.

10. Elin RJ, Hosseini JM, Kestner J, Rawe M, Ruddel M, Nishi HH.
Comparison of automated and manual methods for urinalysis. Am J Clin Pathol. 1986;86(6):731-737.

11. Jeon CH, Lee AJ, Kim KY. Annual report on external quality assessment scheme for urinalysis and faecal occult blood testing in Korea (2014). J Lab Med Qual Assur. 2015;37(4):179-189.

12. Lee AJ, Jeon CH, Kim SG, Suh HS, Bae YC. Comparison of analytical performance between the sysmex UF-100 flow cytometer and the Iris IQ200 urine microscopy system. J Lab Med Qual Assur. 2010;32(1):181-188.

13. Kim KD, Koo SH, Kim EC, Kim JM, Kim CH, Kim JQ, et al. Annual report on external quality assessment in urinalysis in korea (1998). J Clin Pathol \& Quality Control. 1999;21(1): 81-93.

14. Kim JQ, Kim DC, Jo SS. The present situation of quality assurance of urinalysis including urinary sediment analysis based on korean external quality assurance survey and its prospective. J Clin Pathol \& Quality Control. 2000;22(2):265-270.

15. Kim DC, Yoo YM, Jo SS, Park JW, Yoo YM, Kim JQ. Laboratory evaluation of fully automated urine cell analyzer sysmex UF-100. J Clin Pathol \& Quality Control. 2001;23(2):299-306.

16. Koken T, Aktepe OC, Serteser M, Samli M, Kahraman A, Dogan N. Determination of cut-off values for leucocytes and bacteria for urine flow cytometer (UF-100) in urinary tract infections. Int Urol Nephrol. 2002;34(2):175-178. 